\title{
A Multi-attribute Online Advertising Budget Allocation Under Uncertain Preferences
}

\author{
Asignación de presupuesto para publicidad en linea \\ considerando múltiples atributos bajo incertidumbre \\ de preferencias
}

Anu Gupta Aggarwal ${ }^{1} \bowtie$, Aakash $^{2}$

${ }^{1}$ University of Delhi, Delhi, India
${ }^{2}$ University of Delhi, Delhi, India

Department of Operational Research, Faculty of Mathematical Sciences, University of Delhi, Delhi-110007, India.

Email: anugupta@or.du.ac.in

Received on: October $23^{\text {th }}, 2017 \quad$ Accepted on: February $7^{\text {th }}, 2018 \quad$ Available online: May $1^{\text {st }}, 2018$

How to cite this article: A. G. Aggarwal, and Aakash, "A Multi-attribute Online Advertising Budget Allocation Under Uncertain Preferences”, Ing. Sol., vol. 14, no. 25 (Special issue), pp. 10, May 2018. doi: https://doi.org/10.16925/.v14i0.2225

\section{Abstract}

Introduction: The present research was conducted at the University of Delhi in 2017.

Method: Websites were ranked on the basis of feedback from unbiased experts. Later, we proposed an integrated approach by combining ordered weighted averaging (owA) operator with fuzzy analytic hierarchy process (FAHP) for budget allocation.

Results: A numerical example related to a company, which deals with consumer goods and wants to advertise on few e-commerce websites is discussed at the end of the paper. Budget distribution is decided by solving multi-objective maximum-dispersion-minimum-variance (MDMV) OWA and FAHP method.

Conclusions: The proposed methodology aids managerial decisions made by handling multiple attributes simultaneously through industry experts' opinion, and using a simple proportional rule for allocating budget.

Originality: The conventional methods based on reach maximization, exposure or profit cannot meet the budget allocation needs of the modern advertising planning. Firstly, they do not take into consideration multiple attributes of media. Secondly, they do not incorporate the expert opinion and their preferences. To address these problems, we propose a multi-attribute method based on the advertising budget allocation method to divide the budget into individual websites. The attributes under consideration are: system quality, content quality, usage, trust, customer support, online customer feedback, and personalization.

Limitations: In this study, we used a mDMv-owa operator in fuzzy environment but in future occasions, it may be extended to intuitionistic fuzzy domain.

Keywords: budget allocation, electronic commerce, fuzzy analytic hierarchy process, maximumdispersion, minimum variance. 


\title{
Asignación de presupuesto para publicidad en línea considerando múltiples atributos bajo incertidumbre de preferencias
}

\author{
Resumen \\ Introducción: la presente investigación se realizó en la Universidad de Delhi, India, en 2017.
}

Método: se clasifican los sitios web según la retroalimentación de expertos imparciales. Más adelante, proponemos un enfoque integrado que combina el operador de promediado ponderado ordenado (owa) con el proceso de jerarquía analítica difusa (FAHP) para la asignación presupuestaria.

Resultados: al final se analiza un ejemplo numérico relacionado con una empresa que se dedica a bienes de consumo y quiere publicitar en sitios web de comercio electrónico. Se decide cómo distribuir el presupuesto utilizando el método combinado de máxima dispersión y mínima varianza (MDMV), owa y FAHP.

Conclusiones: la metodología propuesta ayuda a tomar decisiones gerenciales al manejar múltiples atributos simultáneamente a partir de la opinión de expertos de la industria, y emplear una regla proporcional simple para asignar el presupuesto.

Originalidad: los métodos convencionales basados en la maximización del alcance, la exposición o los beneficios no cumplen con las necesidades de asignación de presupuesto de la planificación publicitaria moderna. En primer lugar, no toman xen consideración los múltiples atributos de los medios. En segundo lugar, no incorporan la opinión de los expertos y sus preferencias. Para abordar estos problemas, proponemos un método de múltiple atributo basado en el método de asignación de presupuesto publicitario para dividir el presupuesto en sitios web individuales. Los atributos que se tienen en cuenta son: calidad del sistema, calidad del contenido, uso, confianza, atención al cliente, comentarios de los clientes en línea y personalización.

Limitaciones: en este estudio utilizamos un operador momv-owa en un entorno difuso, pero en ocasiones futuras se puede extender al dominio difuso intuicionista.

Palabras clave: asignación presupuestaria, comercio electrónico, proceso de jerarquía analítica difusa, dispersión máxima, varianza mínima

\section{Destinação de verba para publicidade on-line considerando múltiplos atributos sob incerteza de preferências}

\section{Resumo}

Introdução: a presente pesquisa foi realizada na Universidade de Deli, na Índia, em 2017.

Método: as páginas web são classificadas conforme o feedback de especialistas imparciais. Depois, propomos um enfoque integrado, que combina o operador de média ponderada ordenada (owA) com o processo analítico hierárquico difuso (FAHP) para a destinação de verba.

Resultados: finalmente, um exemplo numérico relacionado com uma empresa que se dedica a bens de consumo e quer fazer publicidade em páginas web de comércio eletrônico é analisado. Utiliza-se o método combinado mDMv (maximum-dispersion-minimum-variance, na sigla em inglês), owA e FAHP para decidir como distribuir a verba.

Conclusões: a metodologia proposta ajuda a tomar decisões gerenciais ao manejar múltiplos atributos, simultaneamente, a partir da opinião de especialistas da indústria, e empregar uma regra proporcional simples para destinação de verba.

Originalidade: os métodos convencionais, baseados na maximização do alcance, na exposição ou nos benefícios, não cumprem com as necessidades de destinação de verba do planejamento publicitário moderno. Em primeiro lugar, não consideram os múltiplos atributos dos meios. Em segundo lugar, não incorporam a opinião dos especialistas e as suas preferências. Para abordar esses problemas, propomos um método de múltiplos atributos, baseado no método de destinação de verba publicitário, para dividir as verbas em páginas web individuais. Os atributos que são levados em conta são: qualidade do sistema, qualidade do conteúdo, uso, confiança, atenção ao cliente, comentários dos clientes na rede e personalização.

Limitações: neste estudo, foi utilizado um operador mDmv-owa em um entorno difuso, mas em ocasiões futuras é possível expandir ao domínio difuso intuicionista.

Palavras-chave: comércio eletrônico, destinação de verba, maximum-dispersion, minimum-variance, processo analítico hierárquico difuso. 


\section{Introduction}

Media planning in terms of media selection and allocation of advertising budget has been of immense importance to marketers for a long time. Nowadays, companies spend an enormous amount on the promotion of their products through advertising on different media vehicles such as TV commercials, newspaper, radio, magazine, hoardings, direct mail, internet etc.

Internet is now a prime advertising medium, with millions of users spread worldwide. It has gained popularity because of the relative ease and cost-effectiveness for setting up advertising campaigns while penetrating deep into the customer base spread globally across geographical boundaries. The other advantages offered by Internet as advertising media are the facility to track customer preferences, customization of product and services according to their needs, and feedback obtained by analyzing browsing behavior and comments posted online. Internet further facilitates the fine tuning of campaign parameters by monitoring the effectiveness of the campaign. Now the Internet is affecting every dimension of our life and it has become a vital source of information for customers worldwide. In 2016, ComScore us Media Metrix showed that the population of Internet users has grown $1 \%$ per year [1]. Therefore, rising Internet penetration has changed the way organizations do business and communicate with their customers. Fig. 1 shows numerous advantages that Internet offers as an advertising medium.

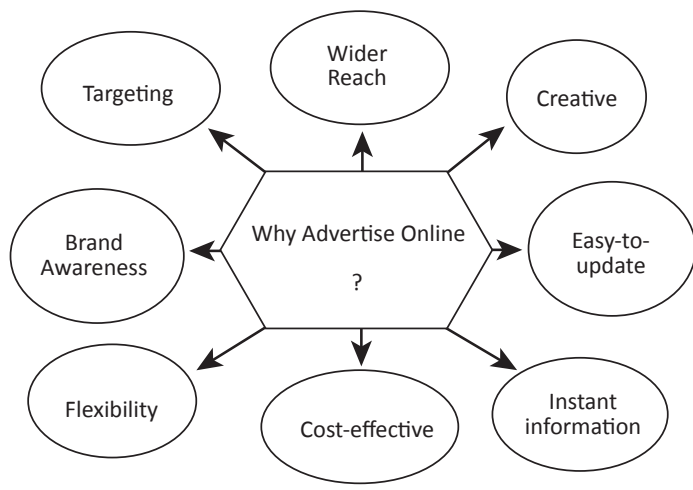

Fig. 1. Reasons to advertise online Reference: the authors
Internet advertising plays an important role for succeeding in technological environment business. A market research report published in 2016 on Digital-Usage-Trend indicates that customers are growingly using Internet to get better knowledge about product and services available at e-commerce websites so that they can easily decide to purchase [1]. In fact, more than $95 \%$ of customers surf e-commerce websites before making purchases over the Internet as well as offline. Hence, ignoring the online advertising on e-commerce websites means losing businesses because a large number of customers are online.

Internet advertising provides the ability to target and retarget the ideal prospects to promote businesses. It can be used to divert traffic to specific websites and build the brand awareness. It has the flexibility to adjust advertising campaigns with clicks or keystrokes. It gives an option to the advertiser for responding to incoming data and change the advertisement according to customer needs.

Online advertising is highly cost-effective as the costs are set on the basis of location, size, and performance demand of advertisement. It gives access to a global audience. Its reach is boundless so advertisement online is more effective and profitable. There is an utmost need to divide the budget judiciously.

In this paper, we propose an innovative approach to the online advertising budget allocation by taking into consideration a number of attributes related to websites so as to judge its popularity on the basis of feedback obtained from experts and customers. To add the opinion of experts we have used maximum-dispersion-minimum-variance ordered weighted averaging (MDMV-OWA). This operator helps to incorporate the uncertainty related with response of the experts by maximizing the amount of information available from them and by minimizing the variance of their opinion. In the next level, we use fuzzy analytic hierarchy process (FAHP) to consider the feedback from customers with respect to the relative importance of different attributes with respect to various websites. We prefer fuzzy AHP over traditional AHP to overcome the subjectivity associated with customers' response. To illustrate the methodology, we have worked out the budget allocation problem by considering top e-commerce websites and their various success attributes such as system quality, content quality, usage, trust, customer support, online 
customer feedback, and personalization. Firstly, we find order preference for five websites through an integrated approach based on MDMV-OWA and fuzzy AHP followed by advertising budget allocation through a ratio rule.

We have formulated a nonlinear multi-objective optimization problem to obtain the weights of multiple attributes related to e-commerce sites through OwA. The use of owA operator for selection purpose is widespread. Sadiq et al. used owA operator to integrate performance indicators for small water utilities [2]. Merigó and Casanovas proposed induced euclidean ordered weighted averaging distance (IEOWAD) operator and applied it to select investment in other countries [3]. We propose an owA operator that can be used to get the weight vector of multiple e-commerce success attributes by maximizing the dispersion of weight vector while minimizing the variance in experts' opinions.

For precision, the MDMV-OWA operator fully utilizes the given information from experts' preferences and minimizes the subjectivity.

\section{Literature Review}

The increasing penetration of the web and improvement in network technology have encouraged firms to invest in online advertisements. The objective of Internet advertising is to reach a maximum number of online users and create awareness about the product or services. In 2015, F\&D proposed a dynamic allocation of advertising budget for web portals through keywords based advertising [4], Danaher et al. (2010) proposed a nonlinear optimization algorithm to select online media vehicles subject to budgetary constraints and also showed the number of advertising impressions that should be purchased and then served from each selected website [5]. Yang et al. (2015) discussed a model to maximize profit through advertising under a budget constraint [6].

The above mentioned models are based on only one or two characteristics in budget allocation, namely reach and budget. Now, there is a growing need to develop a model to allocate advertising budget to various websites on the basis of multiple attributes. A multi criteria based budget allocation method has not been reported yet in the related literature we found.

In this study, we propose a multi criteria-based budget allocation model for dividing advertising budget into a number of e-commerce websites on the basis of multiple success attributes. We have used an integrated MDMV-OWA and fuzzy AHP approach for handling the uncertain preferences of decision makers.

The ordered weighted averaging aggregation operator (OWA) is a multi-criteria decision maker. It was initially introduced by Yager [7] and a number of methods have been proposed for obtaining the weight vector of multiple attributes such as: quantifier guided aggression [7-8] and exponential smoothing [9]. Further, a special owa operator was proposed for maximizing dispersion (MD-OWA) by O' Hagan (1988) under the given level of orness [10]. In 2001, Fullér and Majlender proposed an owA operator for maximizing variance (MD-OWA) subject to given level of orness [11].

The advantage of using MDMV-OwA operator in this study is to simultaneously maximize dispersion while minimizing the variance of weight vectors. This owA operators can handle the tradeoff between multiple objectives by allowing a positive compensation between uncertain preferences, such as: maximum level of satisfaction of one of the attributes can compensate for minimum level of satisfaction for other attribute to some extent. Additionally, to overcome the linguistic comparison scale of AHP, we propose fuzzy- AHP based technique that integrates with MDMV-OWA operator.

We have used genetic algorithms to find the optimal weight vector by maximizing dispersion and minimizing the variance (MDMV) subject to a given level of orness. Genetic algorithm (GA) is one of the random, adaptive and highly parallel optimization algorithms based on the theory of "natural selection and survival of the fittest". GA is initiated by specifying a population of randomly generated solutions for the problem in hand. Then, it involves moving from one set of solutions in one generation to other set of solutions given by developing generations through fitness evaluation, selection, crossover and mutation operators [12]. GA has been extensively applied in many areas by previous researchers, such as, Briza and Naval (2011) who used NSGA-II genetic algorithm to investigate the application of multi-objective optimization to endof-day historical trading [13], and Yeh and Chuang (2011) used multi-objective genetic algorithms to find the set of Pareto-optimal solution [14].

In this paper, we have used non-dominated-and-crowding sorting genetic algorithm II 
(NSGA-II) developed by Deb [15] to optimize our multi-objective problem (MDMV-OWA). This uses a specific population sorting approach, which is initially based on dominance, and then crowding distance is calculated for every individual. The main advantage of using this algorithm is to ensure both convergence and spreading of the solution without the use of external population. Therefore, NSGA-II is accepted as a more efficient multi-objective evolutionary algorithm. The detailed methodology used in this paper is explained in the next section.

\section{Method}

In this paper we have used the multi-objective owA operator combined with maximum-dispersion-minimum-variance ordered weighted averaging operator and fuzzy analytic hierarchy process (MDMV-OWA-FAHP) for allocating budget to number of e-commerce websites according to experts' preferences based on multiple attributes. The MDMV-OWA is used for calculating the weight vector of different attributes and FAHP is used for finding the priority weight of different alternatives. Next, we calculate the value of owA operator $\left(F_{i}\right.$ ) for each website $(i)$ through a formula given by Yager [7]. Finally, we allocate budget to each alternative using a simple proportional rule i.e. the alternatives with higher priority weight are given higher budget in relation to other alternatives.

The MDMv-owa model used in this paper is described as follows:

$$
\begin{aligned}
& \max -\sum_{j=1}^{N} w_{j} \ln w_{j} \\
& \min \frac{1}{N} \sum_{j=1}^{N} w_{j}^{2}-\frac{1}{N^{2}} \\
& \text { s.t. } \quad \beta=\frac{1}{(N-1)} \sum_{j=1}^{N}(N-j) w_{j}, \forall 0 \leq \beta \leq 1 . \\
& \sum_{j=1}^{N} w_{j}=1,0 \leq w_{j} \leq 1 \forall j=1,2, \ldots, N .
\end{aligned}
$$

For instance, when $\mathrm{N}=7$ (Here we took $\mathrm{N}=7$ as the alternative websites that have been judged on the basis of seven attributes), the weight vector of the MDMV-OWA operator can be derived by solving model (1) using genetic algorithm (GA) in MATLAB and the weights are summarized in Table 1.

The FAHP is a multi-criteria decision making technique with qualitative and quantitative decisions, variables which incorporate experts' imprecise judgments [16].

In this study we propose a fuzzy-AHP based model for allocating advertising budget to a number of e-commerce websites. In this hierarchal model, the top level is the goal, i.e., the best e-commerce website. The middle level involves seven attributes, namely, system quality (sQ), content quality (CQ), usage (US), trust (TR), customer support (CS), customer feedback (CF), and personalization (PR). The lowest level describes different website alternatives. Fig. 2 gives the hierarchal structure for budget allocation to different e-commerce websites in

Table 1. The weight vectors $\left(w_{j}\right)$ for various level of orness $(\beta)$

\begin{tabular}{lcccccc}
\hline & \multicolumn{7}{c}{$\beta$} & & & \\
\cline { 2 - 7 } & 0.5 & 0.6 & 0.7 & 0.9 & 0.9 & 1 \\
\hline$W_{1}$ & 0.1429 & 0.2150 & 0.3063 & 0.4286 & 0.6154 & 1.0000 \\
$W_{2}$ & 0.1429 & 0.1862 & 0.2280 & 0.2596 & 0.2478 & 0.0000 \\
$W_{3}$ & 0.1429 & 0.1594 & 0.1626 & 0.1435 & 0.0862 & 0.0000 \\
$W_{4}$ & 0.1429 & 0.1357 & 0.1142 & 0.0787 & 0.0312 & 0.0000 \\
$W_{5}$ & 0.1428 & 0.1174 & 0.0854 & 0.0493 & 0.0165 & 0.0000 \\
$W_{6}$ & 0.1428 & 0.1006 & 0.0616 & 0.0280 & 0.0029 & 0.0000 \\
$W_{7}$ & 0.1428 & 0.0857 & 0.0419 & 0.0123 & 0.0000 & 0.0000 \\
\hline
\end{tabular}

Reference: the authors 
proportion to priority weights calculated on the basis of expert's judgment with respect to seven success attributes.

Fuzzy AHP approach is the combination of triangular fuzzy number (TFNS) and analytical hierarchy process (AHP). The linguistic judgments of the decision maker are converted into the triangular fuzzy numbers (TFNs) for constructing fuzzy pairwise comparison matrices. These pair-wise matrices are used to get the weights of the alternatives. Hence, we have used triangular fuzzy comparison scale for creating pair-wise matrices [17] and extent analysis technique to calculate the weight of each alternative [18].

The steps for the detailed procedure of integrated budget allocation are as follows:

Step 1: Choose the online advertising budget, i.e., $B$. Step 2: Construct the hierarchical structure for evaluating different e-commerce websites alternatives.

Step 3: Construct the pair-wise comparison matrices for the alternatives.

Step 4: Check the consistency of the pair-wise comparison matrices.

Step 5: If the consistency of the matrices does not meet the basic requirements, then go back to step 3 . Step 6: Define the level of orness, $\beta$ and then calculate the MDMV-OWA weight vector $(W)$ using equation (1).

Step 7: Calculate the owA operator F for each website $(i)$ [7].
Step 8: Calculate the budget of each e-commerce website alternative according to the following equation:

$$
B_{i}=B * \frac{F_{i}}{\sum_{i=1}^{n} F_{i}} \quad \forall i=1,2, \ldots \ldots, n
$$

where $F_{i}$ is the owA operator and $B_{i}$ is the budget allocated to the $i^{\text {th }}$ e-commerce website alternative. In the next section we present a numerical application of the Fuzzy- AHP based MDMv-owa budget allocation model.

\subsection{Numerical illustration}

Assume an international consumer's goods company that manufactures and supplies several products belonging to different categories. The marketing manager of the company wants to advertise online to enhance current and future market shares of the company. The detailed procedure is described as follows

\subsubsection{Choose the Internet advertising budget}

The online advertising budget is the total money allocated to various activities for communicating with customers in one financial year. There are some basic criteria for setting online advertising budget, e.g. the percentage of expected revenue (percentage annual revenue), reference point

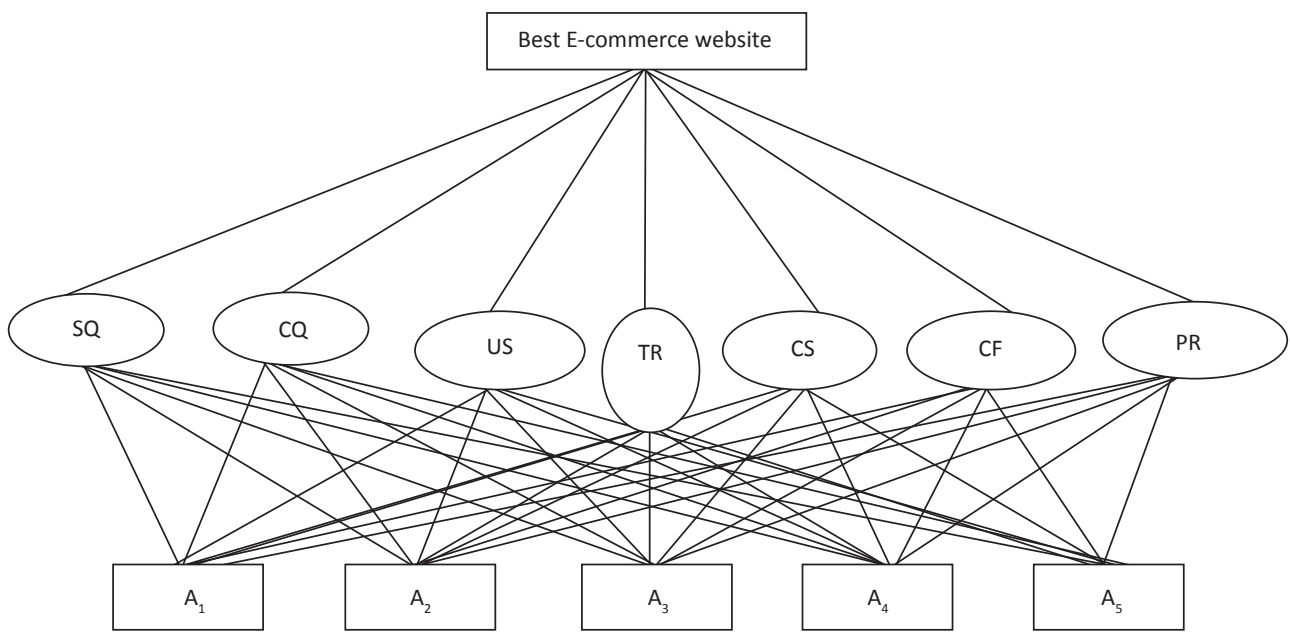

Fig . 2. Hierarchal structure for budget allocation of Internet advertising

Reference: the authors 
(competitors' budget), strategic goals and task (brand awareness, capturing, increasing sales); measurement (return on investment, ROI), historical internet marketing data and analysis (time period, industry, company size), and online advertising channels (e-commerce websites, Google ads, social media, video content, retargeting ads). These criteria are very effective to divide online advertising budgets. For numerical illustration, we set the digital advertising budget $(B)$ for the company to $\$ 50000$ (i.e. $B=\$ 50000$ ).

\subsubsection{Construct the hierarchal structure for budget allocation}

The hierarchal structure for the problem is given in Fig. 2.

\subsubsection{Construct the pair-wise comparison matrices for the alternatives}

The senior experts were invited to form the pairwise matrices based on the past online marketing data, their personal knowledge and experience. The following pairwise-matrices and priority weights for seven attributes are obtained through the technique discussed in the methodology section.

$$
M_{S Q}=\left[\begin{array}{ccccc}
(1,1,1) & (1,3 / 2,2) & (1 / 2,1,3 / 2) & (1,3 / 2,2) & (1,3 / 2,2) \\
(1 / 2,2 / 3,1) & (1,1,1) & (1 / 2,1,3 / 2) & (1,3 / 2,2) & (1,3 / 2,2) \\
(2 / 3,1,2) & (2 / 3,1,2) & (1,1,1) & (1,3 / 2,2) & (3 / 2,2,5 / 2) \\
(1 / 2,2 / 3,1) & (1 / 2,2 / 3,1) & (1 / 2,2 / 3,1) & (1,1,1) & (1 / 2,1,3 / 2) \\
(1 / 2,2 / 3,1) & (1 / 2,2 / 3,1) & (2 / 5,1 / 2,2 / 3) & (2 / 3,1,2) & (1,1,1)
\end{array}\right]
$$

$W_{S Q}=(0.2458,0.2185,0.2458,0.1397,0.1502)$.
Here $W_{S Q}$ represents the priority weight for five alternatives with respect to system quality. Similarly, the priority weights for different alternatives are given in Table 2.

\subsubsection{Calculate the consistency of the pair-wise matrices}

To check the consistency, we convert TFNs into crisp numbers using defuzzification rule [19]. Further, we calculate consistency index (CI) and consistency ratio $(\mathrm{CR})$ for comparing the random index (RI) of each pair-wise matrix with the predefined random index (RI) values proposed by Satty [20].

\subsubsection{Check if the level of consistency meets the basic requirements or not}

We observed that information given by fuzzy pairwise comparison matrix is satisfactory and meets the basic requirements of consistency (i.e. $C R<$ $0.1)$.

\subsubsection{Set the level of orness $(\beta)$ and then calculate the MDMV-OWA weight vector $(W)$}

Here, the level of orness $(\beta)$ is set on the basis of experts' uncertain preferences. If experts are maximally optimistic on their judgment with respect to different alternatives, then the level of orness will be 1 . If the experts are moderate, then the level of orness will be 0.5 . Due to moderate optimistic preferences of e-commerce experts, the level of orness is set to 0.8 .

Table 2. Priority weight for multiple factors with $\lambda_{\max }, C I$ and $C R$

\begin{tabular}{cccccccc}
\hline & $S Q$ & $C Q$ & $U S$ & $T R$ & $C S$ & $C F$ & $P R$ \\
\hline$A_{1}$ & 0.2458 & 0.2932 & 0.4287 & 0.3152 & 0.2370 & 0.5387 & 0.2987 \\
$A_{2}$ & 0.2185 & 0.2412 & 0.3333 & 0.2780 & 0.2370 & 0.1969 & 0.2857 \\
$A_{3}$ & 0.2458 & 0.2611 & 0.1835 & 0.1942 & 0.1789 & 0.0463 & 0.0278 \\
$A_{4}$ & 0.1397 & 0.1972 & 0.0546 & 0.2126 & 0.2134 & 0.1823 & 0.2470 \\
$A_{5}$ & 0.1502 & 0.0074 & 0.0000 & 0.0000 & 0.1337 & 0.0358 & 0.1409 \\
$\lambda_{\max }$ & 5.1025 & 5.1045 & 5.2734 & 5.1439 & 5.2786 & 5.3081 & 5.3376 \\
$C I$ & 0.0256 & 0.0261 & 0.0684 & 0.0360 & 0.0696 & 0.0770 & 0.0844 \\
$C R$ & 0.0229 & 0.0233 & 0.0610 & 0.0321 & 0.0622 & 0.0688 & 0.0754 \\
\hline
\end{tabular}


The weight vector $(W)$ of MDMv-OwA operator for our specific problem (i.e. $N=7$ ) with the specific level of orness is given in Table 1 . These weight vectors can be used to aggregate the information of multiple attributes of e-commerce websites. Now from Table 1, the weight vector for $\beta=0.8$ is:

$\mathrm{W}=\left(\mathrm{w} \_1, \mathrm{w} \_2, \mathrm{w} \_3, \mathrm{w} \_4, \mathrm{w} \_5, \mathrm{w} \_6, \mathrm{w} \_7\right)$

$\mathrm{W}=(0.4286,0.2596,0.1435,0.0787,0.0493,0.0280$, 0.0123).

Now we calculate the value of MDMv-OwA operator for the first alternative $\left(A_{1}\right)$ as follows:

$F_{1}(\mathrm{SQ}, \mathrm{CQ}, \mathrm{US}, \mathrm{TR}, \mathrm{CS}, \mathrm{CF}, \mathrm{PR})=\sum_{i=1}^{7} w_{i} b_{i}$

$F_{1}=0.4386 \times 0.5387+0.2596 \times 0.4287+0.1435$

$\times 0.3152+0.0787 \times 0.2987+0.0493 \times 0.2932+$

$0.0280 \times 0.2458+0.0123 \times 0.2370=0.4352$

where $b_{i}$ is the $i^{\text {th }}$ largest element in the set $\{\mathrm{SQ}, \mathrm{CQ}$, US, TR, CS, CF, PR\}. Similarly, the owA operators for other alternatives $A_{2}, A_{3}, A_{4}$, and $A_{5}$ as $F_{2}=0.2961$, $F_{3}=0.2285, F_{4}=0.2209$, and $F_{3}=0.1233$.

\section{Calculate actual allocated budget}

Based on Eq. (2), using advertising budget $(B)$ and owA operator $\left(F_{i}\right)$ for each alternative of e-commerce website, the allocated budget to each alternative is obtained as follows:

Budget allocated to the first alternative website $\left(A_{1}\right)$ is $=$

$$
B_{1}=B * \frac{F_{1}}{\sum_{i=1}^{5} F_{i}}=50000 * \frac{0.4352}{1.304}
$$

Therefore, $B_{1}=\$ 16687.12$.

Similarly, we get $B_{2}=\$ 11353.53, B_{2}=8761.5$, $B_{3}=8470.09, B_{4}=4227.76$. Here $B_{i}$ 's represents the amount of budget allocation for different alternatives.

\section{Results}

To understand the effectiveness of the proposed fuzzy-AHP based MDMV-OWA budget allocation model we apply our model on a consumer goods company that wants to invest in online advertising on different websites according to experts' uncertain preferences and the total advertising budget of the consumer goods company is $\$ 50000$. We can see from Fig. 3 that the first website $\left(A_{1}\right)$ is more effective than $A_{2}, A_{3}, A_{4}$, and $A_{5}$ because the value of its owA operator $\left(F_{1}\right)$ is much higher than rest of the alternatives.

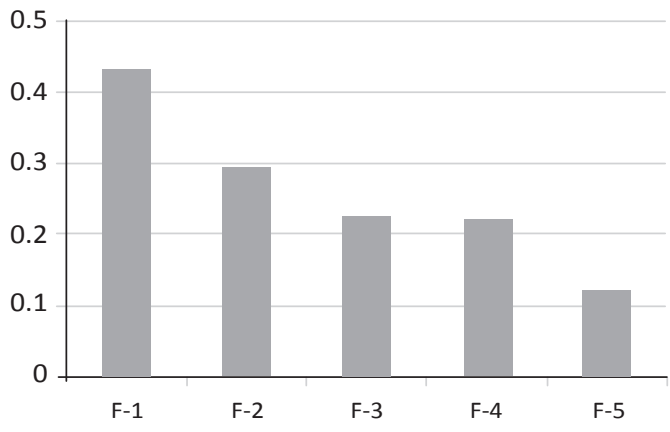

Fig . 3. owA operator $\left(F_{i}\right)$ for each alternative Reference: the authors

Therefore, investing a larger part of total advertising budget on the first alternative $\left(A_{1}\right)$ will be more profitable. We also observe that investing more in the first alternative may maximize the sale, brand value, and awareness about the product because this website has better system quality, content quality, and customer support when compared to the other alternatives. This alternative is preferred because customers find it more trustworthy, it has positive customer feedback, and better personalization for users. According to the above discussion, we can observe that $33.37 \%$ of $\$ 50000$ is allocated to the first alternative of e-commerce websites on the bases of its performance and comparison with other alternatives i.e. \$16,687.12 (see Fig. 4).

Similarly, $22.7 \%$ (i.e. $\$ 11353.53$ ) of total advertising budget goes to the second alternative $\left(A_{2}\right)$, $17.52 \%$ (i.e. $\$ 8761.5$ ) to the third $\left(A_{3}\right), 16.94 \%$ (i.e. $\$ 8470.09$ ) to the fourth $\left(A_{4}\right)$; and $9.45 \%$ (i.e.4727.76) to the fifth alternative $\left(A_{5}\right)$. Here, the value of owA operator for $A_{1}$ is higher (i.e. $F_{1}=0.4352$ ) when compared to the other alternatives $\left(F_{2}=0.2961, F_{3}\right.$ $=0.2285, F_{4}=0.2209$ and $\left.F_{5}=0.1233\right)$. The invest ment in $\left(A_{1}\right)$ is compared to other alternatives and became of higher trust and had more positive costumers' opinion about its content quality and personalization of needs. 


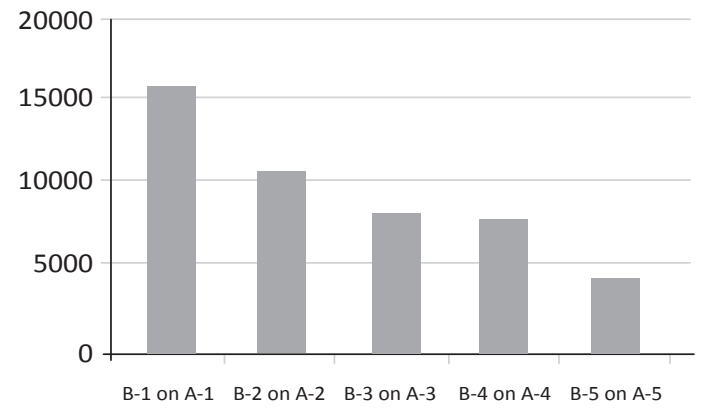

Fig . 4. Allocated budget $\left(B_{i}\right)$ on e-commerce websites' alternatives $\left(A_{i}\right)$

Reference: the authors

\section{Discussion}

The methodology developed for the allocation of advertising budget in different online e-commerce websites has a significant impact in managerial decision making as follows:

- The proposed allocation method overcomes a number of drawbacks associated with traditional methods of advertising planning where the decisions are based on single criteria like reach, budget or profit. But nowadays, management has a vast number of alternatives available which offer additional advantages of reach beyond geographies, to display advertisement based on customer browsing history and shopping preferences.

- Experts' opinions were gathered to derive the priority of different alternatives based on seven success attributes.

- The allocation was based on a simple proportional rule, which is easy to implement and comprehend for the decision makers.

- The methodology proposed in this paper is based on hierarchy of structure, which makes the problem and the alternatives easy to comprehend and offers more clarity for decision making.

- The methodology developed in this paper was applied to a consumer's good company but it may be suitable for other business firms dealing with hospitality, health care or the education industry.

\section{Conclusions}

1. The increasing popularity of Internet among the masses has mandated the managers to revise their advertising strategies and include Internet based medias in their advertising plan.

2. This paper contributes to the research on budget allocation by proposing fuzzy AHP based on MDMV-OWA operator that incorporates the expert's uncertain preferences. To obtain the weighting vector, a non-linear multi-objective programming model which maximizes the dispersion while minimizing the variance from the equal weights was applied.

3. A numerical study on budget allocation for different websites for a consumer goods company is provided to demonstrate the implementation of the technique in practice. A simple owA is used to allocate budget, which suggests allocating budget proportionally to their priority weights.

4. The priority weights of different online media alternatives have been calculated on the basis of expert evaluation of those with respect to a seven criteria system: quality (sQ), content quality (CQ), usage (Us), trust (TR), customer support (Cs), customer feedback (CF), and personalization (PR).

5. The proposed methodology helps in the allocation decision when the advertisement plan is in early stage and expert's opinions may be gathered during focus group studies or through industry experts' interviews.

6. Our research has some limitations which may be worked out in future research. First, we analyzed budget allocation under static conditions. It could be interesting to study when dynamic allocation is made by considering multiple attributes. Secondly, our study takes into consideration the success factor related to different websites but excluded the other attributes like cost per impression, daily online traffic, etc.

7. In this paper, we have proposed a methodology that concentrates on the customers' oriented success factor but definitely in the future, it may be extended to accommodate the website's specific factors also.

\section{References}

[1] K. Sruoginis, "Digital Usage Trends: Mid Year 2016" IAB. New York, United States, June 2015 to June 
2016. Available: http://www.iab.com/wp-content/ uploads/2016/11/Mid-Year-2016-Digital-UsageTrends-FINAL-DRAFT.pdf.

[2] R. Sadiq, M. J. Rodríguez, and S. Tesfamariam, "Integrating indicators for performance assessment of small water utilities using ordered weighted averaging (owA) operators", Expert Systems with Applications, vol. 37, no. 7, pp. 4881-4891, 2010. doi: https:// doi.org/10.1016/j.eswa.2009.12.027

[3] J. M. Merigó and M. Casanovas, "Induced aggregation operators in the Euclidean distance and its application in financial decision making", Expert Systems with Applications, vol. 38, no. 6, pp. 7603-7608. 2011, doi: https://doi.org/10.1016/j.eswa.2010.12.103

[4] G. E. Fruchter and W. Dou, "Optimal budget allocation over time for keyword ads in web portals", Journal of optimization theory and applications, vol. 124 , no. 1 , pp. 157-174, 2005. doi: https://doi. org/10.1007/s10957-004-6470-0

[5] P. J. Danaher, J. Lee, and L. Kerbache, "Optimal internet media selection”, Marketing Science, vol, 29, no. 2, pp. 336-347, 2009. doi: https://doi.org/10.1287/ mksc. 1090.0507

[6] Y. Yang, D. Zeng, Y. Yang, and J. Zhang, "Optimal budget allocation across search advertising markets". INFORMS Journal on Computing, vol. 27, no. 2, pp. 285-300, 2015. DOI: https://doi.org/10.1287/ ijoc.2014.0626

[7] R. R. Yager, "On ordered weighted averaging aggregation operators in multicriteria decision making", IEEE Transactions on systems, Man, and Cybernetics, vol. 18, no. 1, pp. 183-190, 1988. doi: https://doi. org/10.1016/B978-1-4832-1450-4.50011-0

[8] R. R. Yager, "Families of owA operators", Fuzzy sets and systems, vol. 59, no. 2, pp. 125-148, 1993. doi: https://doi.org/10.1016/0165-0114(93)90194-M

[9] D. Filev and R.R. Yager, "On the issue of obtaining owA operator weights", Fuzzy sets and systems, vol. 94, no. 2, pp. 157-169, 1998. doi: https://doi. org/10.1016/S0165-0114(96)00254-0

[10] M. O’Hagan, “Aggregating Template or Rule Antecedents In Real-time Expert Systems With Fuzzy Set Logic", Conference Record - Asilomar Conference on Circuits, Systems \& Computers. 2, 1988, pp. 681-689. doi: https://doi.org/10.1109/ACSSC.1988.754637
[11] R. Fullér and P. Majlender, "An analytic approach for obtaining maximal entropy owA operator weights", Fuzzy Sets and Systems, vol. 124, no. 1, pp. 53-57, 2001. doi: https://doi.org/10.1016/S01650114(01)00007-0

[12] S. Sivanandam and S. Deepa, Introduction to genetic algorithms. New York, USA: Springer Science \& BusinessMedia, 2007. Available: https://xa.yimg. com/kq/groups/86541084/1097235234/name/ Introduction+to+Genetic +Algorithms +Springer+(2008),+354073189X.pdf.

[13] A. C. Briza and P. C. Naval, "Stock trading system based on the multi-objective particle swarm optimization of technical indicators on end-of-day market data", Applied Soft Computing, vol. 11, no. 1, pp. 1191-1201, 2011. doi: https://doi.org/10.1016/j. asoc.2010.02.017

[14] W. C. Yeh and M. C. Chuang, "Using multi-objective genetic algorithm for partner selection in green supply chain problems", Expert Systems with applications, vol. 38, no. 4, pp. 4244-4253, 2011. doi: https:// doi.org/10.1016/j.eswa.2010.09.091

[15] K. Deb, A. Pratap, S. Agarwal, and T. Meyarivan, "A fast and elitist multiobjective genetic algorithm: NSGA-II", IEEE transactions on evolutionary computation, vol. 6, no. 2, pp. 182-197, 2002. doi: https://doi. org/10.1109/4235.996017

[16] C. K. Kwong and H. Bai, "Determining the importance weights for the customer requirements in $\mathrm{QFD}$ using a fuzzy AHP with an extent analysis approach", IIE Transactions, vol. 35, no. 7, pp. 619-626, 2003. doi: https://doi.org/10.1080/07408170304355

[17] F. T. Bozbura, A. Beskese, and C. Kahraman, "Prioritization of human capital measurement indicators using fuzzy AHP”, Expert Systems with Applications, vol. 32, no. 4, pp. 1100-1112, 2007. doi: https://doi. org/10.1016/j.eswa.2006.02.006

[18] D. Y. Chang, "Applications of the extent analysis method on fuzzy AHP", European Journal of Operational Research, vol. 95, no. 3, pp. 649-655, 1996. doi: https://doi.org/10.1016/0377-2217(95)00300-2

[19] J. J. Wang and D. L. Yang, "Using a hybrid multi-criteria decision aid method for information systems outsourcing", Computers \& Operations Research, vol. 34, no. 12, pp. 3691-3700, 2007. doi: https://doi.org/10.1016/j.cor.2006.01.017

[20] A. Saaty, The analytic hierarchy process, New York: Mc Graw Hill, 1980. 